\title{
Sunflower Growth Performance under Tillage or No Tillage Practice, Irrigation Intervals and Nitrogen Fertilization Rates
}

\author{
Khamis A. Mourad, ${ }^{1}$ Ali I. Nawar ${ }^{2}$ and Hassan E. Khalil ${ }^{3}$ \\ ${ }^{1}$ Oil Crops Dept., Field Crops Res. Inst., Agric. Res. Center., Giza, Egypt. \\ ${ }^{2}$ Crop Sci. Dept., Faculty of Agriculture, Alexandria University. \\ ${ }^{3}$ Crop Intensification Section, Field Crops Res. Inst., Agric. Res. Center., Giza, Egypt.
}

\begin{abstract}
Growth expressions of sunflower, supplied with 30,45 , and $60 \mathrm{~kg} \mathrm{~N} / \mathrm{fad}$, were examined under the treatment of two tillage practices (conventional tillage and no tillage applications) and three irrigation intervals (12, 18 and 24 days, between each two successive irrigations) during 2017 and 2018 summer seasons at the Experimental Farm of the Itay-ELBaroud Agricultural Research Station. Responses of plant height, leaf area index, flowering date, stem diameter, head diameter, 1000-seed weight, seed yield/ fad., harvest index and seed oil content in addition to oil yield/ fad. were significant having the maximum records for sunflower with 12 days interval of irrigation. Also, the highest values of plant height, leaf area index, harvest index, seed yield/ plant, during the two seasons, and seed yield /fad, oil yield (in 2017) and 1000-seed weight (in 2018) were achieved with conventional tillage compared to no tillage. Meanwhile, no significant effects were obtained for flowering date, stem diameter and head diameter during the two seasons of study, and 1000-seed weight (in 2017), seed yield and oil yield/ fad (in 2018) based on tillage practice. Increasing the level of nitrogen fertilization up to $60 \mathrm{~kg} / \mathrm{fad}$, significantly increased all studied characters except nitrogen use efficiency (NUE) and oil percent which decreased with increasing nitrogen levels during the two seasons. The interaction of irrigation intervals and tillage practice significantly affected plant height over the two seasons. This trait had maximum values with the shortest irrigation interval (every 12 days) and $60 \mathrm{~kg} \mathrm{~N} / \mathrm{fad}$. The obtained data indicated that 1000-seed weight, seed yield/plant, leaf area index and harvest index were significantly affected by the irrigation interval and nitrogen levels interaction. Meanwhile, high seed and oil yields were achieved with short interval (every 12 days) under conventional tillage and nitrogen levels of 40 and $60 \mathrm{~kg} \mathrm{~N} / \mathrm{fad}$. It is recommended to grow sunflower under conventional tillage practice, with applying irrigation every 12 to 18 days and nitrogen fertilizer at the rate of 45 to $60 \mathrm{~kg} \mathrm{~N} / \mathrm{fad}$, to obtain highest seed and oil yields.
\end{abstract}

Key wards: Sunflower, no tillage, irrigation, nitrogen fertilization, nitrogen use efficiency, seed yield.

\section{INTRODUCTION}

Sunflower is considered to be Egypt's future source of vegetable oil. It can be grown more than twice a year due to being a crop of short duration growth with a wide range of adaptation to climatic conditions. There are different agricultural decisions affecting sunflower growth and productivity performance.

Application of no tillage system (zero tillage) has different advantages, compared to conventional tillage. These include increased land use (Nawar et al., 2017), soil structure improvement, coupled with microbial activity enhancement and improved water retention (Hobbs et al., 2008) a reduction in production cost (e.g. saving labor and fuel), (Erenestein et al., 2012), in addition to flexibility in planting and harvesting (Khalil et al., 2004). However, reasons for tillage include reduction in soil resistance to root penetration and stimulation of plant growth (Mirleau-Thebaud, 2017), pest control in short crop rotations or sequences (Nawar et al., 2017), together with soil fertilizers and plant residues incorporation and other amendments, leading to a decrease of $\mathrm{N}$ use (Langeroodi, 2015).

Development of irrigated agriculture depends, not only on sufficient water being available, but also on the efficient use of that water. Both quantity and distribution of water has a significant impact on seed and oil yields of sunflower (Kazemei et al., 2009). Adequate water for initial plant growth is important for producing a plant able to respond to later irrigation. Therefore, there should be a modification in agriculture plan through and between each successive irrigation (Boydak et al., 2007).

Nitrogen controls biomass production through its effects on the plant leaf number and leaf generation (Khalil et al., 2008) and assimilates production. The increase in $\mathrm{N}$ uptake, as $\mathrm{N}$ level increases, led to greater vegetative growth, hence, greater photoassimilates partitioning into seeds (Nawar et al., 2017). However, other researchers reported that the increase in $\mathrm{N}$ level led to higher leaf area index (LAI) with a reduction in both light intensity and net assimilation rate (NAR) due to between leaves mutual shading, resulting in a yield decline (Nawar et al., 2017). Nevertheless, the practice of $\mathrm{N}$ application, more than crop requirements, may be a reason for $\mathrm{N}$ transformation into $\mathrm{NO}_{3}$ followed by $\mathrm{N}$ leaching. This study was conducted to evaluate sunflower response to $\mathrm{N}$ fertilization under the effects of tillage practice and water irrigation intervals. 


\section{MATERIALS AND METHODS}

Two field experiments were conducted at the Experimental Farm in Itay El- Baroud, Agricultural Research Station, Agricultural Research Center (ARC), during 2017 and 2018 summer seasons to evaluate growth performance of sunflower (Helianthus annuus L.) Sakha 53 cultivar in response to tillage practices, water irrigation intervals and nitrogen fertilization rates. Three irrigation treatments (irrigation every 12, 18 and 24 days), two tillage practices (conventional tillage (CT) and no tillage (NT)) and three nitrogen levels (30, 45 and $60 \mathrm{~kg} / \mathrm{fad})$ were used. Treatments were arranged in a split-split plot design with three replications, where the main plots were designated for irrigation treatments, and sub-plots included tillage practices, while nitrogen fertilization levels were allocated to the sub-sub plots. Sowing dates were on $10^{\text {th }}$ and $15^{\text {th }}$ May in the two successive seasons, respectively. The plants were manually seeded in ridges spaced at $60 \mathrm{~cm}$ apart and $20 \mathrm{~cm}$ between hills. The net size of sub-sub plot area was $7.2 \mathrm{~m}^{2}$. Thinning of plants was done at 20 days after sowing to one plant/ hill to keep 30000 plants/ fad. Superphosphate $\left(\begin{array}{llll}15.5 & \% & \mathrm{P}_{2} \mathrm{O}_{5}\end{array}\right)$ and potassium sulfate $\left(48 \% \mathrm{~K}_{2} \mathrm{O}\right)$ were added to experimental soil at preparation at the rate of 200 and $50 \mathrm{~kg} / \mathrm{fad}$, respectively. Nitrogen (as ammonium nitrate $33.5 \%$ ) was applied in two equal doses (at first and second irrigations). All other cultural practices were applied as recommended for sunflower crop production. Soil chemical analysis of the two seasons of the experimental site is presented in (Table 1).

Ten guarded and random plants were harvested from the $2^{\text {nd }}$ and $3^{\text {th }}$ ridges in each sub-sub plot to measure plant height $(\mathrm{cm})$, stem diameter $(\mathrm{cm})$, head diameter $(\mathrm{cm})$, weight of 1000 seeds $(\mathrm{g})$ and seed weight/ head $(\mathrm{g})$. Seed and biological yields per fad. were obtained from the inner two ridges then transformed to ton/fad. Leaf area was determined according to the methodology of Benincasa (1988), with modifications to determine leaf area index. After separating the leaves of five plants, 40 leaf disks with a known area $\left(1.77 \mathrm{~cm}^{2}\right)$ were sampled in each experimental plot, which was considered as the leaf area of the sample (LA sample). Then, after drying in a forced-air oven at

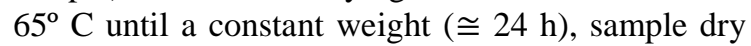
mass (DM sample) and leaf dry mass (LDM) were determined. Leaf area (LA) was obtained through the equation:

$\mathrm{LA}=(L A$ sample $\times L D M) \div$ DMsample, then leaf area index was calculated according to the formula of Hunt (1990): Unit leaf area per plant / unit ground area occupied by plant. Nitrogen use efficiency (NUE) was calculated using the formula suggested by Moll et al. (1982) by dividing seed yield (GW) by nitrogen $(\mathrm{N})$ applied to the soil plus mineral nitrogen in soil before sowing (NS) as follows: $\{\mathrm{NUE}=\mathrm{GW} / \mathrm{N}+\mathrm{NS}\}$

The harvest index (HI) was calculated using the formula:

$\mathrm{HI}=$ economic yield / total biomass $\times 100$.

Seed oil percentage was determined according to (A.O.A.C. 1995). Oil yield (kg/ fad) was calculated by multiplying seed oil percentage by seed yield/ fad as follows:-

Oil yield/ fad $=$ Oil \% X seed yield/ fad.

The obtained data were analyzed according to Snedecor and Cochran (1967). The treatment means were compared using Least significant difference (LSD) at $5 \%$ level of probability. The analysis of variance (ANOVA) was computed using CoStat V 6.4 (2005) program.

\section{RESULTS AND DISCUSSION}

\section{Effect of irrigation intervals on sunflower traits:}

Data in Tables (2, 3 and 4) revealed that all studied characters were significantly affected by irrigation intervals. As shown in Table (2), significant differences were found in plant height as affected by the irrigation intervals. The tallest plants were obtained under irrigation every 12 days. On the opposite, the shortest plants were measured at 24 days interval over the two seasons. Irrigation every 12 days interval increased water availability which increased sunflower growth vigor in terms of increasing stem length. Likewise, stem diameter had the same trend for such trait in both seasons. These results are in harmony with those reported by Mohammadi et al. (2013). Besides, data presented in Table (2) showed that number of days to $50 \%$ flowering gradually decreased as a result of increasing irrigation interval from 12 to 24 days. Sunflower leaf area index (LAI) was significantly influenced by irrigation water interval in both seasons (Table 3). That trait increased with decreasing the interval between each two successive irrigations. Increasing water availability every 12 days interval promoted a rapid leaf expansion to increase LAI. These results are in agreement with those reported by Sinclair and Gardner (1998).

Data presented (Table 2) showed the effects of irrigation intervals on head diameter. Frequent irrigation interval (irrigation every 12 days) increased head diameter. This might be due to an increased growth characters in this treatment. The lengthening of irrigation interval (24 days) had a small head diameter. Similar results were obtained by EL-Naim and Ahmed (2010). This reduction in head diameter was due to the effect of reduced moisture supply in vegetative growth.

Ghani et al. (2000) and Bakht et al. (2010) reported that such increase could be due to higher net assimilation rate due to better utilization of the available water which, ultimately, led to better 
development of head. A heavier 1000-seed weight was obtained with irrigation every 12 days (Table 3). This may be attributed to the availability of water, especially in early stages of growth, that may have enhanced growth resulting in higher photosynthetic capacity (higher LAI values) and assimilates production which were, later, translocated to the seeds. On the other hand, extending irrigation interval to 18 and 24 days resulted in a significant decrease in 1000-seed weight. Shortage in water supply, due to extended irrigation intervals, especially at critical growth stages, will result in reduced vegetative growth and lower translocation rate of photoassimlates to the seeds, hence reducing seed weight (Kaya and Kolsarici, 2011).

Results presented in Table (3) indicated that seed weight/ head showed a significant response to irrigation interval. Data showed that the longer irrigation interval was associated with the higher reduction in such trait. This could be explained by the exposure of plants to drought during flowering enforcing plants to bloom earlier and produce less filled seeds due to lower translocation of assimilates from leaves to seeds. Such findings agreed with those of Kazemei et al. (2009) and Kaya and Kolsarici (2011). Data also revealed that irrigation of sunflower every 12-day intervals enhanced the plants for higher assimilates production, greater filled seed which increased 1000-seed weight to make seed weight/ head higher than at 18 and 24days irrigation intervals. EL-Hafez et al. (2002), Ashoub et al. (2003), Kazemei et al. (2009) and Kaya and Kolsarici (2011) found similar findings.

Means presented in Table (4) showed the effect of irrigation intervals on seed yield/ fad. The treatment of irrigation every 12 days resulted in increased seed yield since it exhibited a better performance of growth characters and yield components. In contrast, the extending of irrigation interval from 12 to 24 days resulted in a significant seed yield reduction. This refers to the effects of water stress on sunflower growth performance and yield. This is in line with Mirleau-Thebaud (2017) and Langeroodi (2015). Regarding harvest index, data showed that this trait had the same trend of seed yield/ fad over the two seasons (Table 3). Maximum and minimum records of such trait were obtained, consequently, from irrigation intervals of
12 and 24 days. Superiority of HI might be ascribed to higher seed yield compared to straw yield (data not presented). Sinclair and Gardner (1998) reported that increase in plant economic part, relative to uneconomic, increases plant HI.

Analysis of data (Table 4) showed the contribution of irrigation intervals on oil percentage and oil yield /fad. The beneficial effect of the period of irrigation intervals indicated that the shorter the irrigation interval, the greater oil $\%$ and oil yield. The highest soil water availability produced the higher values of such traits which could be associated with carbohydrates availability for oil synthesis at the expense of protein production, finally increasing oil \% and oil yield (Mohammadi et al., 2013).

\section{Effect of tillage practices on sunflower traits:}

Significant differences were found for plant height, 1000-seed weight, seed yield/ plant, leaf area index, harvest index and seed yield /fad (Tables 2, 3 and 4), while, no significant differences were found for flowering date, stem diameter, head diameter and seed oil percent as affected by tillage practices over the two seasons. As for plant height, data exhibited that the tallest plants were recorded with the conventional tillage (CT) treatment compared to no tillage during the two seasons. This superiority of CT might be due to reducing soil's penetration resistance to roots which allowed the spread of a large root system that lead to a strong vegetative growth. The same trend was found for seed yield/ plant and per faddan over the two years. Also, results for 1000-seed weight in 2017 differed from that in 2018, where, no significant differences were found in 2017 season between the two tillage practices whereas, in the second season 2018, conventional tillage gave higher value of 1000 -seed weight than no tillage. Besides, significant differences were observed for harvest index as affected by tillage practices, where conventional tillage recorded higher values than no tillage in 2017 season, while the opposite trend was observed in 2018. Concerning oil yield/ fad, significant differences were found between CT and NT in 2017 season only. The highest values of oil yield/ fad. $(427.53 \mathrm{~kg})$ were recorded by $\mathrm{CT}$, while, no significant differences were found in 2018 season.

Table 1: Soil chemical analysis of the two seasons of the experimental site.

\begin{tabular}{|c|c|c|c|c|c|c|}
\hline \multirow{2}{*}{ seasons } & \multirow{2}{*}{ depth } & \multirow{2}{*}{$\mathbf{p H}$} & \multirow{2}{*}{$\mathrm{EC}, \mathrm{dS} / \mathrm{m}$} & $\mathbf{N}$ & $\mathbf{P}$ & $\mathbf{K}$ \\
\hline & & & & \multicolumn{3}{|c|}{ mg/kg soil } \\
\hline \multirow{2}{*}{2017} & $0-30$ & 8.12 & 2.22 & \multirow{2}{*}{144} & \multirow{2}{*}{1.46} & \multirow{2}{*}{171.12} \\
\hline & $30-60$ & 8.47 & 2.35 & & & \\
\hline 2018 & $0-30$ & 8.06 & 4.12 & 149 & 1.47 & 168.43 \\
\hline
\end{tabular}


Table 2: Plant height $(\mathrm{cm})$, days to $50 \%$ of flowering, stem diameter $(\mathrm{cm})$ and head diameter $(\mathrm{cm})$ as influenced by irrigation intervals, tillage practices and nitrogen fertilization during 2017 and 2018 seasons.

\begin{tabular}{|c|c|c|c|c|c|c|c|c|}
\hline \multirow[b]{2}{*}{ A-Irrigation intervals } & \multicolumn{2}{|c|}{ Plant height (cm) } & \multicolumn{2}{|c|}{$\begin{array}{l}\text { days to } 50 \% \text { of } \\
\text { flowering }\end{array}$} & \multicolumn{2}{|c|}{$\begin{array}{c}\begin{array}{c}\text { Stem } \\
\text { diameter }\end{array} \\
(\mathbf{c m})\end{array}$} & \multicolumn{2}{|c|}{$\begin{array}{c}\text { Head diameter } \\
(\mathrm{cm})\end{array}$} \\
\hline & 2017 & 2018 & 2017 & 2018 & 2017 & 2018 & 2017 & 2018 \\
\hline 12 days & $211.6 \mathrm{a}^{(1)}$ & $204.5 \mathrm{a}$ & $54.94 \mathrm{a}$ & $54.66 \mathrm{a}$ & $2.16 \mathrm{a}$ & $1.49 \mathrm{a}$ & $21.20 \mathrm{a}$ & $22.08 \mathrm{a}$ \\
\hline 18 days & $208.2 \mathrm{~b}$ & $199.1 \mathrm{~b}$ & $54.77 \mathrm{a}$ & $54.55 \mathrm{a}$ & $2.12 \mathrm{a}$ & $1.44 \mathrm{a}$ & $20.91 \mathrm{a}$ & $21.41 \mathrm{~b}$ \\
\hline 24 days & $180.1 \mathrm{c}$ & $176.9 \mathrm{c}$ & $53.77 \mathrm{~b}$ & $53.44 \mathrm{~b}$ & $1.90 \mathrm{~b}$ & $1.22 \mathrm{~b}$ & $19.49 \mathrm{~b}$ & $18.93 \mathrm{c}$ \\
\hline \multicolumn{9}{|l|}{ B-Tillage practices } \\
\hline $\mathrm{CT}$ & $201.2 \mathrm{a}$ & $194.8 \mathrm{a}$ & $54.00 \mathrm{a}$ & $54.14 \mathrm{a}$ & $2.05 \mathrm{a}$ & $1.39 \mathrm{a}$ & $20.69 \mathrm{a}$ & $20.89 \mathrm{a}$ \\
\hline NT & $198.8 \mathrm{~b}$ & $192.2 \mathrm{~b}$ & $54.48 \mathrm{a}$ & $54.29 \mathrm{a}$ & $2.07 \mathrm{a}$ & $1.37 \mathrm{a}$ & $20.38 \mathrm{a}$ & $20.73 \mathrm{a}$ \\
\hline \multicolumn{9}{|l|}{ C-Nitrogen levels } \\
\hline N 30 & $187.3 \mathrm{c}$ & $177.6 \mathrm{c}$ & $53.88 \mathrm{~b}$ & $54.05 \mathrm{~b}$ & $1.90 \mathrm{c}$ & $1.12 \mathrm{c}$ & $19.50 \mathrm{~b}$ & $19.19 \mathrm{c}$ \\
\hline $\mathrm{N} 45$ & $206.2 \mathrm{~b}$ & $196.4 \mathrm{~b}$ & $54.61 \mathrm{a}$ & $\begin{array}{c}54.33 \\
\mathrm{ab} \\
\end{array}$ & $2.10 \mathrm{~b}$ & $1.43 \mathrm{~b}$ & $20.75 \mathrm{a}$ & $21.17 \mathrm{~b}$ \\
\hline N 60 & $211.4 \mathrm{a}$ & $206.5 \mathrm{a}$ & $55.61 \mathrm{a}$ & $54.72 \mathrm{a}$ & $2.18 \mathrm{a}$ & $1.52 \mathrm{a}$ & $21.34 \mathrm{a}$ & $22.06 \mathrm{a}$ \\
\hline \multicolumn{9}{|l|}{ Interactions } \\
\hline $\mathrm{A} \times \mathrm{B}$ & $* *$ & $* *$ & NS & NS & NS & NS & NS & NS \\
\hline $\mathrm{A} \times \mathrm{C}$ & NS & NS & NS & NS & NS & NS & NS & NS \\
\hline $\mathrm{B} \times \mathrm{C}$ & NS & NS & NS & NS & NS & NS & NS & NS \\
\hline $\mathrm{A} \times \mathrm{B} \times \mathrm{C}$ & NS & NS & NS & NS & NS & NS & NS & NS \\
\hline
\end{tabular}

Table 3: 1000-seed weight (g), seed yield/ plant (g), leaf area index (LAI) and harvest index (HI) as influenced by irrigation intervals, tillage practices and nitrogen fertilization during 2017 and 2018 seasons.

\begin{tabular}{|c|c|c|c|c|c|c|c|c|}
\hline \multirow[b]{2}{*}{ A-Irrigation intervals } & \multicolumn{2}{|c|}{$\begin{array}{l}\text { 1000-seed weight } \\
(\mathrm{g})\end{array}$} & \multicolumn{2}{|c|}{$\begin{array}{c}\text { Seed yield/ plant } \\
(\mathrm{g})\end{array}$} & \multicolumn{2}{|c|}{$\begin{array}{c}\text { Leaf area } \\
\text { index (LAI) }\end{array}$} & \multicolumn{2}{|c|}{$\begin{array}{c}\text { Harvest index } \\
\text { (HI) }\end{array}$} \\
\hline & 2017 & 2018 & 2017 & 2018 & 2017 & 2018 & 2017 & 2018 \\
\hline 12 days & $85.16 \mathrm{a}^{(1)}$ & $73.90 \mathrm{a}$ & $70.67 \mathrm{a}$ & $64.46 \mathrm{a}$ & $4.87 \mathrm{a}$ & $4.81 \mathrm{a}$ & $37.31 \mathrm{a}$ & $32.18 \mathrm{a}$ \\
\hline 18 days & $81.02 \mathrm{~b}$ & $72.51 \mathrm{~b}$ & $65.28 \mathrm{~b}$ & $62.88 \mathrm{~b}$ & $4.86 \mathrm{a}$ & $4.80 \mathrm{a}$ & $35.10 \mathrm{~b}$ & $30.97 \mathrm{~b}$ \\
\hline 24 days & $70.91 \mathrm{c}$ & $62.76 \mathrm{c}$ & $53.65 \mathrm{c}$ & $50.23 \mathrm{c}$ & $4.82 \mathrm{c}$ & $4.77 \mathrm{~b}$ & $30.29 \mathrm{c}$ & $24.08 \mathrm{c}$ \\
\hline \multicolumn{9}{|l|}{ B-Tillage practices } \\
\hline $\mathrm{CT}$ & $79.15 \mathrm{a}$ & $70.58 \mathrm{a}$ & $64.18 \mathrm{a}$ & $62.03 \mathrm{a}$ & $4.85 \mathrm{a}$ & $4.82 \mathrm{a}$ & $35.32 \mathrm{a}$ & $28.30 \mathrm{~b}$ \\
\hline NT & $78.91 \mathrm{a}$ & $68.86 \mathrm{~b}$ & $62.22 \mathrm{~b}$ & $56.35 \mathrm{~b}$ & $4.84 \mathrm{~b}$ & $4.77 \mathrm{~b}$ & $33.15 \mathrm{~b}$ & $29.85 \mathrm{a}$ \\
\hline \multicolumn{9}{|l|}{ C-Nitrogen levels } \\
\hline N 30 & $70.29 \mathrm{c}$ & $62.75 \mathrm{c}$ & $54.62 \mathrm{c}$ & $51.53 \mathrm{c}$ & $4.81 \mathrm{c}$ & $4.76 \mathrm{c}$ & $29.84 \mathrm{c}$ & $25.92 \mathrm{c}$ \\
\hline $\mathrm{N} 45$ & $82.40 \mathrm{~b}$ & $70.07 \mathrm{~b}$ & $64.87 \mathrm{~b}$ & $60.73 \mathrm{~b}$ & $4.86 \mathrm{~b}$ & $4.80 \mathrm{~b}$ & $35.05 \mathrm{~b}$ & $29.80 \mathrm{~b}$ \\
\hline N 60 & $84.41 \mathrm{a}$ & $76.35 \mathrm{a}$ & $70.11 \mathrm{a}$ & $65.30 \mathrm{a}$ & $4.88 \mathrm{a}$ & $4.82 \mathrm{a}$ & $37.81 \mathrm{a}$ & $31.50 \mathrm{a}$ \\
\hline \multicolumn{9}{|l|}{ Interactions } \\
\hline $\mathrm{A} \times \mathrm{B}$ & NS & NS & NS & NS & NS & NS & NS & NS \\
\hline$A \times C$ & $* *$ & $* *$ & $*$ & $* *$ & $* *$ & $* *$ & $* *$ & $* *$ \\
\hline $\mathrm{B} \times \mathrm{C}$ & NS & NS & NS & NS & NS & NS & NS & NS \\
\hline $\mathrm{A} \times \mathrm{B} \times \mathrm{C}$ & NS & NS & NS & NS & NS & NS & NS & NS \\
\hline
\end{tabular}

$(\mathrm{NS})=$ Not significant, $(*)=$ Significant at 0.05 and $(* *)=$ Significant at 0.01 levels of probability.

(1) Means followed by the same letter are not significant.

$\mathrm{CT}=$ conventional tillage 
NT= no tillage

Table 4: Nitrogen use efficiency (NUE), seed yield/ fad (kg), oil (\%) and oil yield/ fad (kg) as influenced by irrigation intervals, tillage practices and nitrogen fertilization rates during 2017 and 2018 seasons.

\begin{tabular}{|c|c|c|c|c|c|c|c|c|}
\hline \multirow[b]{2}{*}{ A-Irrigation intervals } & \multicolumn{2}{|c|}{$\begin{array}{c}\begin{array}{c}\text { Nitrogen use } \\
\text { efficiency }\end{array} \\
\end{array}$} & \multicolumn{2}{|c|}{$\begin{array}{c}\text { Seed yield/ fad } \\
(\mathrm{kg})\end{array}$} & \multicolumn{2}{|c|}{$\begin{array}{l}\text { Oil } \\
(\%) \\
\end{array}$} & \multicolumn{2}{|c|}{$\begin{array}{c}\text { Oil yield/ fad } \\
(\mathrm{kg})\end{array}$} \\
\hline & 2017 & 2018 & 2017 & 2018 & 2017 & 2018 & 2017 & 2018 \\
\hline 12 days & $\begin{array}{ll}------ \\
\end{array}$ & -------- & $1204.6 \mathrm{a}^{(1)}$ & $1127.4 \mathrm{a}$ & $38.77 \mathrm{a}$ & $39.19 \mathrm{a}$ & $468.1 \mathrm{a}$ & $442.2 \mathrm{a}$ \\
\hline 18 days & -------- & --------- & $1122.3 \mathrm{~b}$ & $1103.6 \mathrm{~b}$ & $39.00 \mathrm{a}$ & $39.18 \mathrm{a}$ & $437.7 \mathrm{~b}$ & $433.0 \mathrm{a}$ \\
\hline 24 days & $\begin{array}{ll}------- \\
-\end{array}$ & ---------- & $914.6 \mathrm{c}$ & $901.6 \mathrm{c}$ & $37.77 \mathrm{a}$ & $37.82 \mathrm{~b}$ & $345.6 \mathrm{c}$ & $340.9 \mathrm{~b}$ \\
\hline \multicolumn{9}{|l|}{ B-Tillage practices } \\
\hline $\mathrm{CT}$ & -------- & ------- & $1098.9 \mathrm{a}$ & $1045.3 \mathrm{a}$ & $38.74 \mathrm{a}$ & $38.88 \mathrm{a}$ & $427.5 \mathrm{a}$ & $407.5 \mathrm{a}$ \\
\hline NT & $\begin{array}{ll}------ \\
\end{array}$ & $\begin{array}{ll}------- \\
\end{array}$ & $1062.1 \mathrm{~b}$ & $1043.2 \mathrm{a}$ & $38.29 \mathrm{a}$ & $38.58 \mathrm{a}$ & $406.8 \mathrm{~b}$ & $403.3 \mathrm{a}$ \\
\hline \multicolumn{9}{|l|}{ C-Nitrogen levels } \\
\hline N 30 & $31.22 \mathrm{a}$ & $30.75 \mathrm{a}$ & $936.7 \mathrm{c}$ & $922.5 \mathrm{c}$ & $37.97 \mathrm{~b}$ & $38.36 \mathrm{~b}$ & $356.4 \mathrm{c}$ & $354.4 \mathrm{~b}$ \\
\hline $\mathrm{N} 45$ & $24.57 \mathrm{~b}$ & $23.87 \mathrm{~b}$ & $1103.9 \mathrm{~b}$ & $1074.5 \mathrm{~b}$ & $39.69 \mathrm{a}$ & $39.64 \mathrm{a}$ & $440.0 \mathrm{~b}$ & $427.3 \mathrm{a}$ \\
\hline N 60 & $19.98 \mathrm{c}$ & $18.93 \mathrm{c}$ & $1198.9 \mathrm{a}$ & $1135.6 \mathrm{a}$ & $37.88 \mathrm{~b}$ & $38.2 \mathrm{~b}$ & $455.0 \mathrm{a}$ & $434.3 \mathrm{a}$ \\
\hline \multicolumn{9}{|l|}{ Interactions } \\
\hline $\mathrm{A} \times \mathrm{B}$ & NS & NS & NS & NS & $\mathrm{NS}$ & NS & NS & NS \\
\hline $\mathrm{A} \times \mathrm{C}$ & NS & NS & NS & NS & NS & NS & NS & NS \\
\hline $\mathrm{B} \times \mathrm{C}$ & NS & NS & NS & NS & NS & NS & NS & NS \\
\hline $\mathrm{A} \times \mathrm{B} \times \mathrm{C}$ & NS & $\mathrm{NS}$ & $* *$ & $* *$ & $\mathrm{NS}$ & NS & $* *$ & $* *$ \\
\hline
\end{tabular}

(NS) $=$ Not significant, $(*)=$ Significant at 0.05 and $(* *)=$ Significant at 0.01 levels of probability.

(1) Means followed by the same letter are not significant.

$\mathrm{CT}=$ conventional tillage

$\mathrm{NT}=$ no tillage

\section{Effect of nitrogen levels on sunflower traits:}

Analyzed data showed that all studied characters were significantly affected by nitrogen levels (Tables 2, 3 and 4). Days to 50\% flowering increased with increasing nitrogen level. This result was in accordance with those published by Ali (1998). The same trend was found for plant height, stem diameter, head diameter, 1000-seed weight, seed yield/ plant, leaf area index (LAI), harvest index (HI), seed yield/ fad and oil yield/fad. Seed oil percentage, on the other hand, increased significantly with increasing $\mathrm{N}$ level from 30 to 45 $\mathrm{kg} \mathrm{N} / \mathrm{fad}$ then decreased significantly with increasing $\mathrm{N}$ level to $60 \mathrm{~kg} \mathrm{~N} /$ fad. That increase in studied characters is closely related to the nitrogen role in plants which includes enhancement of several biological processes and controlling plant organs growth. This conclusion has been reported by several investigators including Fageria (2004), Blairnelly et al. (2006) and Mohammadi et al. (2013). Increasing $N$ levels led to significant increases in photosynthetic ability, hence production of assimilates and dry matter which led to increase in yield and yield components and vegetative organs (Mohammadi et al., 2013). Furthermore, the results obtained for oil percentage (Table 4) reported significant differences among the three levels of nitrogen over the two seasons. Data showed that increasing $\mathrm{N}$ level above $45 \mathrm{~kg} \mathrm{~N} /$ fad decreased oil percentage. These results might be attributed to the increased $\mathrm{N}$ supply that intensified the synthesis of protein at the expense of fatty acids synthesis and thus reducing the oil content of the seeds, and also the negative relation between protein and oil (Mohammadi et al., 2013).

In addition, variations in economic return, with regard to the invested yield/ one $\mathrm{kg}$ nitrogen were recorded. Data showed an inverse relationship between that trait and nitrogen rates, since maximum and minimum responses of 30.98 and $19.45 \mathrm{~kg} / \mathrm{N}$ unit, as an average of the two seasons, respectively were observed for 30 and $60 \mathrm{~kg} \mathrm{~N} / \mathrm{fed}$, respectively. Increasing $\mathrm{N}$ fertilization level might decrease nitrogen use efficiency in increasing sunflower production leading to yield/ one nitrogen yield decrease. Gutschick (1993) and Khalil (2003) reported the increase in nitrogen use efficiency (NUE) at optimum availability of nitrogen, also as external nutrient concentration in soil decreased.

\section{Two-factor interactions:}

The interaction between irrigation intervals and tillage practices $(\mathrm{A} \times \mathrm{B})$ was highly significant, only, for plant height, while no significance was found for the remaining characters (Tables 2, 3 and 4). Positive and significant changes in plant height, as affected by conventional tillage under 12 days irrigation intervals were observed to achieve 216.78 and $213.61 \mathrm{~cm}$, as compared to 206.44 and 195.37 $\mathrm{cm}$ with no tillage. Meanwhile, the shortest plants $(184.55$ and $188.42 \mathrm{~cm})$ were obtained under no 
tillage with irrigation every 24 days intervals compared to 175.75 and $165.24 \mathrm{~cm}$ under conventional tillage and 24 days interval during the two seasons, respectively (Table 5). Superiority of plant height under no tillage with irrigation every 24 days intervals might be due to the effect of no tillage on weed low germination (Yalcin and Cakir, 2006) and to the ability of no tillage to improve water use efficiency of plants under water stress than conventional tillage. These results are in complete agreement with those obtained by Samarajeewa et al. (2006).

As shown in Tables (3 and 4), significant and highly significant interactions were found between irrigation intervals and nitrogen fertilization rates in some characters (1000-seed weight, seed yield/ plant, leaf area index and harvest index), while no significance was found for other characters. The highest leaf area index means (4.91 and 4.86) were obtained when irrigation was applied every 12 days with $60 \mathrm{~kg}$ nitrogen/ fad during the two seasons, while the lowest values of such trait (4.80 and 4.78) were obtained when the period between irrigations was increased to 24 days and decreasing nitrogen fertilizer to $30 \mathrm{~kg} \mathrm{~N} /$ fad (Table 8). Increasing leaf area index, by increasing nitrogen fertilizer under conventional tillage, represent the role of nitrogen and tillage practice in enhancement of growth traits of sunflower crop. These results are in harmony with those of Massignam et al. (2009) who reported that nitrogen fertilization significantly affected growth, physiological and metabolic procedures of sunflower, and Mohammadi et al. (2013) who reported that increases in soil moisture availability (by increasing number of irrigations) increased sunflower agronomic traits. The same trend of leaf area index was found for 1000-seed weight, seed yield/ plant and harvest index (HI), as affected by interaction between irrigation intervals and nitrogen fertilizer as shown in Tables (6, 7 and 9). Increasing
$\mathrm{N}$ availability and water uptake (with the shortest water interval) increased LAI and photoassimilates production leading to increase in seed weight and seed yield, hence, increasing harvest index. These findings are in accordance with those reported by Paolo and Rinaldi (2008), Tsilalts and Maslaris (2008), Rafiq et al. (2010) and Nasim et al. (2012).

Interaction between irrigation intervals, tillage practices and nitrogen fertilization levels:

Significant decreases were observed in seed yield/ fad with delay in irrigation interval from 12 to 24 days with low level of nitrogen fertilizer $(30 \mathrm{~kg}$ $\mathrm{N}$. $\mathrm{fad}^{-1}$ ) under conventional tillage (CT), while, the best values of this trait were obtained with increasing nitrogen fertilizers to $60 \mathrm{~kg} \mathrm{~N}$. fad ${ }^{-1}$ and shortening irrigation interval to 12 days under conventional tillage in the first season (Table 10). In the second season, the highest values (1273.77, 1261.80 and $1248.65 \mathrm{~kg}$ ) were achieved by CT with 60 and $45 \mathrm{~kg} \mathrm{~N}$. fad ${ }^{-1}$ under irrigation every 12 days and $60 \mathrm{~kg} \mathrm{~N}$. fad ${ }^{-1}$ under irrigation every 18 days, respectively. With respect to oil yield $\mathrm{fad}^{-1}$, the results showed that significant differences were observed based on the interaction between irrigation intervals, tillage practice and nitrogen fertilization in a similar way to seed yield /fad, although no significant differences were recorded for oil percent and the other traits. The maximum seed and oil yields/ fad. were produced from applying $60 \mathrm{~kg}$ N/fad fertilization (Killi, 2004). Seed yield and its attributes significantly increased, but oil percentage was decreased with increasing nitrogen fertilizer rates (Naseem et al., 2011).

The data showed that to obtain high yields of edible oil and seeds, it was recommended to apply $60 \mathrm{~kg} \mathrm{~N} / \mathrm{fad}$ to sunflower with water irrigation every 12 days interval, in addition to the application of tillage practice under the conditions of the agricultural region.

Table 5: The interaction between irrigation intervals and tillage practices for plant height in 2017 and 2018 seasons.

\begin{tabular}{lcccccc}
\hline & \multicolumn{3}{c}{2017} & \multicolumn{3}{c}{2018} \\
\cline { 2 - 7 } & Irrigation. 12 & Irrigation. 18 & Irrigation. 24 & Irrigation. 12 & Irrigation. 18 & Irrigation. 24 \\
\hline $\mathrm{CT}$ & $216.7 \mathrm{a}^{(1)}$ & $211.1 \mathrm{~b}$ & $175.7 \mathrm{e}$ & $213.6 \mathrm{a}$ & $205.4 \mathrm{~b}$ & $165.4 \mathrm{f}$ \\
\hline $\mathrm{NT}$ & $206.4 \mathrm{c}$ & $205.3 \mathrm{c}$ & $184.5 \mathrm{~d}$ & $195.3 \mathrm{c}$ & $192.7 \mathrm{~d}$ & $188.4 \mathrm{e}$ \\
\hline
\end{tabular}

(1) Means followed by the same letter are not significantly different at 0.05 level of probability.

Table 6: The interaction between irrigation intervals and nitrogen fertilization for 1000 -seed weight in 2017 and 2018 seasons.

\begin{tabular}{ccccccc}
\hline & \multicolumn{3}{c}{$\mathbf{2 0 1 7}$} & \multicolumn{3}{c}{$\mathbf{2 0 1 8}$} \\
\cline { 2 - 7 } & Irrigation 12 & Irrigation 18 & Irrigation 24 & Irrigation 12 & Irrigation 18 & Irrigation 24 \\
\hline $\mathrm{N} 30$ & $76.56 \mathrm{c}^{(1)}$ & $70.56 \mathrm{e}$ & $63.75 \mathrm{f}$ & $65.26 \mathrm{e}$ & $64.66 \mathrm{e}$ & $58.33 \mathrm{~g}$ \\
\hline $\mathrm{N} 45$ & $87.86 \mathrm{~b}$ & $86.08 \mathrm{~b}$ & $73.26 \mathrm{~d}$ & $74.81 \mathrm{c}$ & $74.3 \mathrm{c}$ & $61.11 \mathrm{f}$ \\
\hline $\mathrm{N} 60$ & $91.06 \mathrm{a}$ & $86.43 \mathrm{~b}$ & $75.73 \mathrm{c}$ & $81.63 \mathrm{a}$ & $78.56 \mathrm{~b}$ & $68.85 \mathrm{~d}$ \\
\hline
\end{tabular}

(1) Means followed by the same letter are not significantly different at 0.05 level of probability. 
Table 7: The interaction between irrigation intervals and nitrogen fertilization for seed yield / plant in 2017 and 2018 seasons.

\begin{tabular}{lcccccc}
\hline & \multicolumn{3}{c}{$\mathbf{2 0 1 7}$} & \multicolumn{3}{c}{$\mathbf{2 0 1 8}$} \\
\cline { 2 - 7 } & Irrigation 12 & Irrigation 18 & Irrigation 24 & Irrigation 12 & Irrigation 18 & Irrigation 24 \\
\hline $\mathrm{N} 30$ & $60.39 \mathrm{~d}^{(1)}$ & $57.99 \mathrm{~d}$ & $45.49 \mathrm{f}$ & $57.23 \mathrm{~d}$ & $54.34 \mathrm{e}$ & $43.03 \mathrm{~g}$ \\
\hline $\mathrm{N} 45$ & $72.55 \mathrm{~b}$ & $66.68 \mathrm{c}$ & $55.36 \mathrm{e}$ & $66.21 \mathrm{c}$ & $66.07 \mathrm{c}$ & $49.91 \mathrm{f}$ \\
\hline $\mathrm{N} 60$ & $79.06 \mathrm{a}$ & $71.17 \mathrm{~b}$ & $60.10 \mathrm{~d}$ & $69.94 \mathrm{a}$ & $68.22 \mathrm{~b}$ & $57.73 \mathrm{~d}$ \\
\hline
\end{tabular}

(1) Means followed by the same letter are not significantly different at 0.05 level of probability.

Table 8: The interaction between irrigation intervals and nitrogen fertilization for leaf area index in 2017 and 2018 seasons.

\begin{tabular}{ccccccc}
\hline & \multicolumn{5}{c}{$\mathbf{2 0 1 7}$} & \multicolumn{3}{c}{$\mathbf{2 0 1 8}$} \\
\cline { 2 - 7 } & Irrigation 12 & Irrigation 18 & Irrigation 24 & Irrigation 12 & Irrigation 18 & Irrigation 24 \\
\hline $\mathrm{N} 30$ & $4.83 \mathrm{e}^{(1)}$ & $4.82 \mathrm{f}$ & $4.80 \mathrm{~g}$ & $4.80 \mathrm{e}$ & $4.79 \mathrm{ef}$ & $4.78 \mathrm{~g}$ \\
\hline $\mathrm{N} 45$ & $4.87 \mathrm{c}$ & $4.88 \mathrm{~b}$ & $4.82 \mathrm{f}$ & $4.83 \mathrm{c}$ & $4.84 \mathrm{bc}$ & $4.79 \mathrm{ef}$ \\
\hline $\mathrm{N} 60$ & $4.91 \mathrm{a}$ & $4.88 \mathrm{~b}$ & $4.84 \mathrm{~d}$ & $4.86 \mathrm{a}$ & $4.85 \mathrm{~b}$ & $4.81 \mathrm{~d}$ \\
\hline
\end{tabular}

(1) Means followed by the same letter(s) are not significantly different at 0.05 level of probability.

Table 9: The interaction between irrigation intervals and nitrogen fertilization for harvest index (HI) in 2017 and 2018 seasons.

\begin{tabular}{lcccccc}
\hline & \multicolumn{5}{c}{$\mathbf{2 0 1 7}$} & \multicolumn{3}{c}{$\mathbf{2 0 1 8}$} \\
\cline { 2 - 7 } & Irrigation 12 & Irrigation 18 & Irrigation 24 & Irrigation 12 & Irrigation 18 & Irrigation 24 \\
\hline $\mathrm{N} 30$ & $31.82 \mathrm{e}^{(1)}$ & $30.20 \mathrm{f}$ & $27.51 \mathrm{~g}$ & $29.62 \mathrm{c}$ & $28.71 \mathrm{c}$ & $19.44 \mathrm{e}$ \\
\hline $\mathrm{N} 45$ & $38.70 \mathrm{~b}$ & $36.54 \mathrm{c}$ & $29.90 \mathrm{f}$ & $32.71 \mathrm{~b}$ & $31.93 \mathrm{~b}$ & $24.76 \mathrm{~d}$ \\
\hline $\mathrm{N} 60$ & $41.4 \mathrm{a}$ & $38.56 \mathrm{~b}$ & $33.46 \mathrm{~d}$ & $34.21 \mathrm{a}$ & $32.26 \mathrm{~b}$ & $28.03 \mathrm{c}$ \\
\hline
\end{tabular}

(1) Means followed by the same letter are not significantly different at 0.05 level of probability.

Table 10: The interaction between irrigation intervals, tillage practices and nitrogen fertilization for seed yield/ fad in 2017 and 2018 seasons.

\begin{tabular}{lccccccc}
\hline \multicolumn{7}{c}{$\mathbf{2 0 1 7}$} & \multicolumn{2}{c}{$\mathbf{2 0 1 8}$} \\
\hline Irri. 12 & CT & $1084.4 \mathrm{efg}(1)$ & $1362.9 \mathrm{~b}$ & $1537.5 \mathrm{a}$ & $1054.4 \mathrm{c}$ & $1261.8 \mathrm{a}$ & $1273.7 \mathrm{a}$ \\
Irri. 12 & $\mathrm{NT}$ & $981.0 \mathrm{hi}$ & $1095.6 \mathrm{efg}$ & $1166.2 \mathrm{de}$ & $959.9 \mathrm{~d}$ & $1056.3 \mathrm{c}$ & $1158.2 \mathrm{~b}$ \\
Irri. 18 & $\mathrm{CT}$ & $1038.6 \mathrm{gh}$ & $1186.2 \mathrm{~d}$ & $1297.5 \mathrm{c}$ & $977.2 \mathrm{~d}$ & $1244.2 \mathrm{a}$ & $1248.6 \mathrm{a}$ \\
Irri. 18 & $\mathrm{NT}$ & $960.1 \mathrm{ij}$ & $1113.9 \mathrm{defg}$ & $1136.5 \mathrm{def}$ & $940.3 \mathrm{~d}$ & $1081.4 \mathrm{c}$ & $1130.2 \mathrm{~b}$ \\
Irri. 24 & $\mathrm{CT}$ & $656.0 \mathrm{l}$ & $818.5 \mathrm{k}$ & $908.4 \mathrm{j}$ & $710.2 \mathrm{~g}$ & $755.9 \mathrm{f}$ & $862.6 \mathrm{e}$ \\
Irri. 24 & $\mathrm{NT}$ & $899.7 \mathrm{j}$ & $1057.9 \mathrm{fg}$ & $1147.2 \mathrm{de}$ & $893.0 \mathrm{e}$ & $1047.7 \mathrm{c}$ & $1140.5 \mathrm{~b}$ \\
\hline
\end{tabular}

(1) Means followed by the same letter(s) are not significantly different at 0.05 level of probability.

Table 11: The interaction between irrigation intervals, tillage practices and nitrogen fertilization for oil yield / fad in 2017 and 2018 seasons.

\begin{tabular}{lccccccc}
\hline \multicolumn{9}{c}{$\mathbf{2 0 1 7}$} & \multicolumn{3}{c}{$\mathbf{2 0 1 8}$} \\
\hline Irri. 12 & $\mathrm{CT}$ & $416.7 \mathrm{de}$ & $\mathbf{N 4 5}$ & $\mathbf{N 6 0}$ & $\mathbf{N 3 0}$ & $\mathbf{N 4 5}$ & $\mathbf{N 6 0}$ \\
Irri. 12 & $\mathrm{NT}$ & $372.9 \mathrm{f}$ & $435.3 \mathrm{~d}$ & $435.3 \mathrm{~d}$ & $374.6 \mathrm{~cd}$ & $420.7 \mathrm{~b}$ & $436.3 \mathrm{~b}$ \\
Irri. 18 & $\mathrm{CT}$ & $398.0 \mathrm{e}$ & $486.2 \mathrm{c}$ & $492.9 \mathrm{c}$ & $376.1 \mathrm{~cd}$ & $508.9 \mathrm{a}$ & $478.7 \mathrm{a}$ \\
Irri. 18 & $\mathrm{NT}$ & $371.4 \mathrm{f}$ & $441.8 \mathrm{~d}$ & $435.7 \mathrm{~d}$ & $362.6 \mathrm{de}$ & $431.7 \mathrm{~b}$ & $439.9 \mathrm{~b}$ \\
Irri. 24 & $\mathrm{CT}$ & $242.7 \mathrm{i}$ & $316.4 \mathrm{~h}$ & $342.0 \mathrm{~g}$ & $266.3 \mathrm{~g}$ & $291.0 \mathrm{fg}$ & $324.4 \mathrm{f}$ \\
Irri. 24 & $\mathrm{NT}$ & $335.4 \mathrm{gh}$ & $412.6 \mathrm{de}$ & $424.3 \mathrm{de}$ & $339.5 \mathrm{ef}$ & $398.3 \mathrm{bcd}$ & $425.7 \mathrm{~b}$ \\
\hline
\end{tabular}

(1) Means followed by the same letter(s) are not significantly different at 0.05 level of probability. 


\section{REFERENCES}

Ali, M. (1998). Response of sunflower (Helianthus annuus L.) hybrids to various levels of nitrogen and phosphorus. M.Sc. Thesis. Department of Agronomy, Khyber Pakhtunkhwa Agricultural University Peshawar, Pakistan. 23-58.

A.O.A.C. (1995). Official Methods of Analysis of the Association of Official Analytical Chemists. $15^{\text {th }}$ Ed. Published by the association of official analytical chemists. INC. Suite 400, 200 Wilson Boulevard Arlington. Virginia 2221 USA, $69-90$.

Ashoub, M. A., I. M. A. Abdel- Aziz, M. M. Shahin and M. N. Gohar (2003). Impact of irrigation and magnesium fertilization on yield, yield components and chemical contents of sunflower. Arab Universities J. Agric Sci., (11): 191- 204.

Bakht, J., M. Shafi and M. Yousaf (2010). Effect of irrigation on physiology and yield of sunflower. Pak. J. Bot., (42): 1317 - 1326.

Benincasa, M. M. P. Análise de crescimento de plantas. Jaboticabal: FUNEP, 1988. 42p.

Blairnelly, R.D., A.R. Faulkner and P.R. Poullton (2006). Long term management impacts on soil C, N and physical fertility. Soil and Tillage Research, (91); 30- 38.

Boydak, E., D. Karaaslan, M. Simsek, S. Gereek, H. Kimak, Y. Kassap and I. Oztrunk (2007). Effect of irrigation methods and irrigation intervals on yield and some yield components of sesame growing in semi-arid area. Agron. J., (6): $434-443$.

El-Hafez, S.A.A., A.A. El- Sabbah, A.Z. El- Bably and A. Abou- Ela (2002). Evaluation of sprinkler irrigated sunflower in North Delta, Egypt. Alex. J. Agric. Res., (47): 147-152.

EL-Naim, A.M. and M.F. Ahmed (2010). Effect of Irrigation Intervals and Inter- row Spacing on Yield, Yield Components and Water Use Efficiency of sunflower (Helianthus annuus L). Journal of Applied Sciences Research, 6(9): 1446-1451.

Erenestein, O., K. Sayre, P. Wall, J. Helin, and J. Dixon (2012). Conservation agriculture in maize and wheat- based system in the (sub) tropics: lessons from adaptation initiatives in south Asia, Mexico and southern Africa, J. Sustain Agric., (36): 80 -206.

Fageria, N. K. (2004). Nitrogen. Pp 31- 90. In "The Use of Nutrients in Crop Plants". CRC Press, Florida, USA.

Ghani, A., M. Hussain and M.S. Qureshi (2000). Effect of different irrigation regimes on the growth and yield of sunflower. Inter. J. Agriculture and Biology, (2): 334-335.
Gutschick, V.P. (1993). Nutrient-limited growth rates: roles of nutrient-use efficiency and of adaptations to increase uptake rate. Journal of Experimental Botany, 44/258: 41-51.

Hunt, R. (1990). Basic Growth analysis. Published by the Academic Division of Unwin Hyman Ltd., London. p. 55-72.

Hobbs, P.R., K. Sayre and R. Gupta (2008). The role of conservation agriculture in sustainable agriculture. Philos. Trans. R. Soc. B. 363: 543555.

Kaya, M.D. and O. Kolsarici (2011). Seed yield and oil content of some sunflower (Helianthus annuus L.) hybrids irrigated at different growth stages. Agric. J. Biotech., (10): 4591 - 4595.

Kazemei, S. A., M. Edalat and A. Shekoof (2009). Interaction effects of deficit irrigation and row spacing on sunflower (Helianthus annuus L.) growth, seed yield and oil yield. Afr. J. Agric. Res. (4): 1165 - 1170.

Khalil, H. E., A.I. Nawar and A.S.M. Kamel (2004). Response of sunflower to multiseasonal crop sequences under different regimes of NPK fertilization. Alex. J. Agric. Res., (49): 13- 23.

Khalil, H.E., H. M. Ibrahim and A.I. Nawar (2008). Defoliation time and N- levels for sunflower as a forage and oil crop. J. Adv. Agric. Res., (13): 749- 764.

Khalil, H.E. (2003). Response of sunflower to different preceding crops and nitrogen fertilization levels. Minofia J. Agric. Res,(28): $1899-1913$

Killi, F. (2004). Influence of Different Nitrogen Levels on Productivity of Oilseed and Confection Sunflowers (Helianthus annuus L.) Under Varying Plant populations. International Journal of Agriculture \& Biology, 6(4): 594-598.

Langeroodi, A.R.S. (2015). Sunflower and soil response to seven years of tillage residue management and nitrogen fertilizer. Turk. J. field crops; (20): 194- 202.

Massignam, A.M., S.C. Chapman, G.L. Hammer and S. Fukai (2009). Physiological determinants of maize and sunflower (Helianthus annuus L.) grain yield as affected by nitrogen supply. Field Crops Research 113: 256-267. https://www.cabdirect.org/cabdirect/abstract/2 $\underline{0093248881}$.

Mohammadi, K., G. Heidari, M. Javaheri, A. Rokhzadi, T.K. Nezhad, Y. Soharabi and R. Talebi (2013). Agronomic traits of high oleic sunflower hybrid in different tillage systems. Industrial Crops and Production (44): 446451. 
Moll, R.M., E.J. Kamprath and W.A. Jakson (1982). Analysis and interpretation which contribute to efficiency of nitrogen utilization. Agron. J. 74: 562-564.

Nasim, W., A. Ahmad, A. Wajid, J. Akhtar and D. Muhammad (2011). Nitrogen effects on growth and development of sunflower hybrids under agro- climatic conditions of Multan Pakistan J. Bot., 43(4): 2083-2092.

Nasim, W., A. Ahmed, H.M. Hammad, H.J. Chaudhary and H.F.H. Munis (2012). Effect of nitrogen on growth and yield of sunflower under semi-arid conditions of Pakistan. Pak.J.Bot. (44): $634-648$.

Nawar, A.I., Kh.A. Abou- Zeid and H.E. Khalil (2017). Impact of tillage intensity, NPK fertilization and weed control on seed yield and yield components of flax in newly reclaimed lands. Egypt. J. Agron, (39): 179194.

Paolo, E.D. and M. Rinaldi (2008). Yield response of corn to irrigation and nitrogen fertilization in a Mediterranean environment. Field Crops Res., (105): 202: 210.

Rafiq, M.A., A. Ali, M.A. Malik and M. Hussain (2010). Effect of fertilizer levels and plant densities on yield and protein contents of autumn plants. Pak. J. Agric. Sci., (47): 201208.
Samarajeewa, K.B.D.P., T. Horiuchi and S. Oba (2006). Finger millet (Eleucine corocana L. Garetn) as a cover crop on weed control growth and yield of soybean under different tillage systems. Soil Tillage Res. 90: 93-99.

Mirleau-Thebaud, V., J. Dayde and J.V. Scheiner (2017). The influence of soil compaction and conventional tillage on sunflower's (Helianthus annuиs L.) below ground system. International Journal of Experimental Botany, 86: 53-67.

Sinclair, T.R. and E.P. Gardner (1998). Environmental limits to plant production. p. 63- 78. In "Principles of Ecology in Plant Production" CBA, New York, USA.

Snedecor, G.W. and W.G. Cochran (1967). Statistical Methods. Sixth ed. Iowa State University Press, USA.

Tsilalts, J.T and N. Maslaris (2008). Evaluation of leaf area prediction model proposed for sunflower. Photosynthetica, (46): 294- 297.

Yalcin, H. and E. Cakir (2006). Tillage effects and energy efficiencies of subsoiling and direct seeding in light soil on yield of second crop corn for silage in western Turkey. Soil Tillage Res. 90: 250-255. 


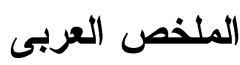

\section{سلولك النمو فى دوار الشمس تحت مستويات مختلفة من خدمة الحرث وفترات الري والتسميد النيتروجينى

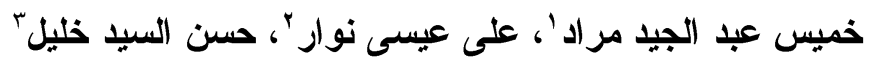

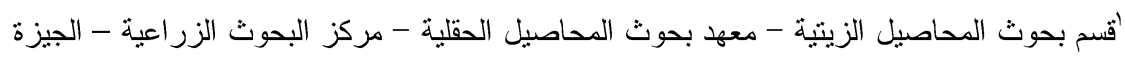 \\ "آقسم علوم المحاصبل - كلية الزراعة - جامعة الاسكندرية \\ "قنسم بحوث النكثيف المحصولى - معهد بحوث المحاصيل الحقلية - مركز البحوث الزراعية - الجيزة
}

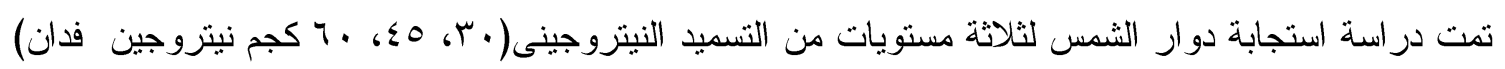

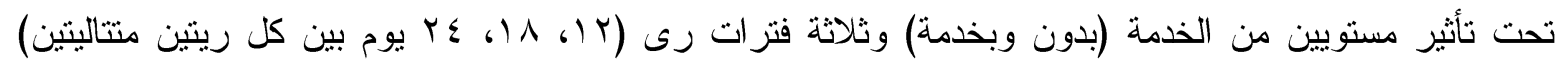
ويمكن إيجاز أهم النتائج المتحصل علينها كالأتى:كانت إستجابة إرتفاع النبات ودليل مساحة الورقة وميعاد التزهير وسمك الساق وقطر القرص ووزن الآلف بذرة

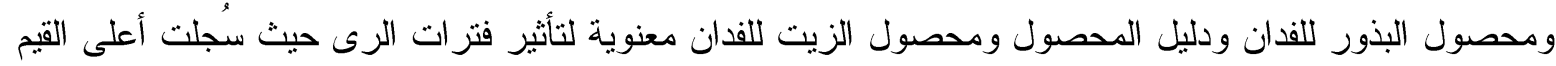
لهذه الصفات تحت ظروف الرى كل r ا يوم. كذلك أظهرت النتائج أن عمليات الخدمة كانت الأفضل من عدم الخدمة لصفات كل من إرتفاع النبات ودليل

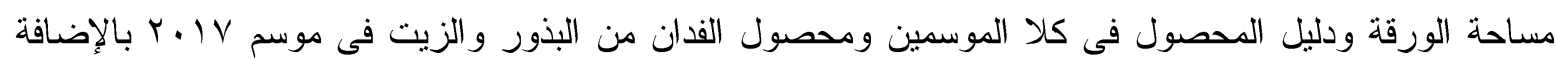

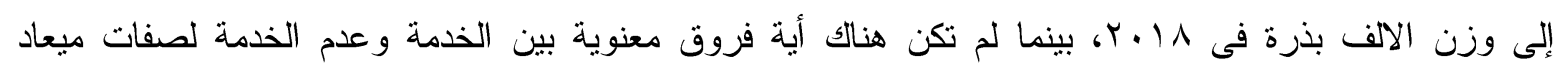

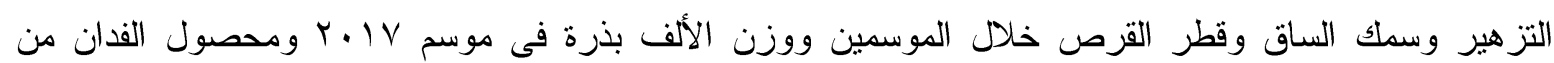

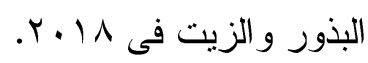

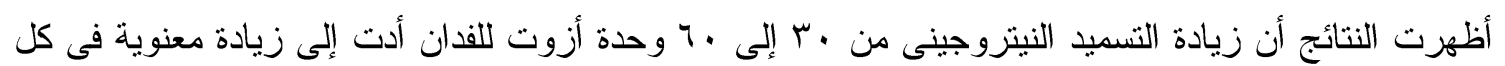
الصفات تحت الدراسة فيما ماعدا صفتى نسبة الزيت وكفاءة استخدام النيتزوجين و التى تتاقصت بزيادة المستوى النيتزوجينى. كان تأثير التفاعل بين فترات الرى والخدمة معنويا لصفة طول النبات فقط فى حين كان التفاعل بين فترات الرى ومستويات التسميد النيتروجينى معنوى لصفات كل من وزن ال ـ . . . بذرة ودليل مساحة الورقة ودليل الحصاد ووزن البذورللنبات وبينما كان التفاعل بين العوامل الثلاثة تحت الدراسة (فترات الرى ومستويات الخدمة و التسميد النيتزوجينى) معنويا لصفتى محصول البذورو الزيت للفيت للفدان.

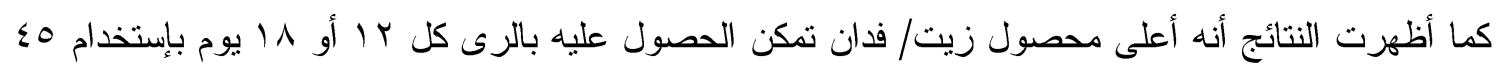

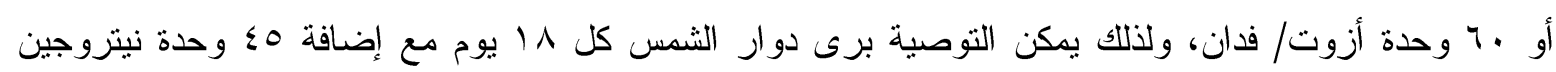
للفدان للحصول على أعلى محصول زيت. 